\title{
Paleo-Perspectives on Potential Future Changes in the Oxidative Capacity of the Atmosphere Due to Climate Change and Anthropogenic Emissions
}

\author{
Becky Alexander ${ }^{1}$. Loretta J. Mickley ${ }^{2}$
}

Published online: 5 May 2015

(C) Springer International Publishing AG 2015

\begin{abstract}
The oxidizing capacity of the atmosphere, defined as the global mean tropospheric abundance of the hydroxyl radical $(\mathrm{OH} \cdot)$, strongly influences air pollution by controlling the lifetimes of gaseous pollutants and the production of particulate matter. Predicting future changes in $\mathrm{OH} \cdot$ due to anthropogenic emissions and climate change is of interest to air quality managers, but it is difficult because of multiple competing effects. Models of atmospheric chemistry suggest that these competing effects buffer significant change in $\mathrm{OH} \cdot$ in the past and in the near future. However, proxy-based observations for past changes in $\mathrm{OH} \cdot$ and other oxidants over the preindustrial-industrial and glacial-interglacial time scales suggest much larger changes than models estimate. Model sensitivity studies show that variability in past and future $\mathrm{OH} \cdot$ is highly sensitive to relative emissions of reactive nitrogen and carbon, water vapor, lightning, and stratospheric ozone, implying that one or more of these variables is highly sensitive to climate.
\end{abstract}

Keywords Hydroxyl radical · Ozone · Atmospheric chemistry

This article is part of the Topical Collection on Air Pollution

Becky Alexander

beckya@uw.edu

Loretta J. Mickley

mickley@fas.harvard.edu

1 Department of Atmospheric Sciences, University of Washington, 408 ATG Building, Seattle, WA 98195-1640, USA

2 School of Engineering and Applied Sciences, Harvard University, 29 Oxford St., Cambridge, MA 02138, USA

\section{Introduction}

The atmosphere plays a key role in biogeochemical cycles on Earth by oxidizing reduced trace gases emitted from natural and anthropogenic sources. The oxidizing capacity of the atmosphere is nominally defined as the global mean tropospheric abundance of the hydroxyl radical $(\mathrm{OH} \cdot)$. Other oxidants, such as the nitrate radical $\left(\mathrm{NO}_{3} \cdot\right)$, ozone $\left(\mathrm{O}_{3}\right)$, hydrogen peroxide $\left(\mathrm{H}_{2} \mathrm{O}_{2}\right)$, the sum of peroxy radicals $\left(\mathrm{HO}_{2} \cdot+\mathrm{RO}_{2} \cdot\right)$, and reactive halogens (e.g., $\mathrm{Cl} \cdot \mathrm{BrO} \cdot$ ) also play a key role in the oxidizing capacity of the atmosphere, and the abundance of each oxidant is influenced by the other oxidants through highly non-linear oxidant cycling reactions (Fig. 1). For example, $\mathrm{O}_{3}$ acts as a precursor to $\mathrm{OH}$, and the oxidation of $\mathrm{CH}_{4}$ by $\mathrm{OH} \cdot$ provides a source of $\mathrm{RO}_{2}$. The oxidizing capacity of the atmosphere affects air quality by determining the lifetime and formation of gas-phase pollutants such as carbon monoxide (CO) and $\mathrm{O}_{3}$ and by contributing to the formation of particulate matter via gas-to-particle conversion. Thus, information about how the oxidizing capacity of the atmosphere responds to human activity and natural phenomena is of key interest for air pollution concerns.

An understanding of potential future changes in the oxidizing capacity of the atmosphere is also relevant for air quality managers, as variability in the oxidizing capacity of the atmosphere may influence the ability of any given region to remain in compliance with local air quality standards. The abundance of $\mathrm{OH}$ - may change due to changes in anthropogenic emissions of pollutants or changes in climate. Anthropogenic emissions of $\mathrm{NO}_{\mathrm{x}}\left(=\mathrm{NO}+\mathrm{NO}_{2}\right)$, originating primarily from fossil fuel combustion [1], drive production of both tropospheric $\mathrm{O}_{3}$ and $\mathrm{OH}$. Anthropogenic emissions of reduced carbon species such as $\mathrm{CO}$ (from fossil-fuel production) and methane $\left(\mathrm{CH}_{4}\right.$, from agriculture and other activities) serve as a source of $\mathrm{O}_{3}$ but a sink of $\mathrm{OH}$. As a result of increasing anthropogenic 
Fig. 1 Schematic of the coupling between $\mathrm{HO}_{x}\left(=\mathrm{OH} \cdot+\mathrm{HO}_{2} \cdot+\right.$ $\left.\mathrm{RO}_{2} \cdot\right), \mathrm{NO}_{x}\left(=\mathrm{NO}+\mathrm{NO}_{2}\right)$, and reactive halogens $(X=\mathrm{Br}, \mathrm{Cl})$ and impact on $\mathrm{OH} \cdot \mathrm{O}_{3}$, and $\mathrm{H}_{2} \mathrm{O}_{2}$ production in the troposphere. Parameters in blue (where $\mathrm{NMHC}=$ non-methane hydrocarbons) lead to $\mathrm{OH}$. destruction, while parameters in red lead to $\mathrm{OH} \cdot$ production

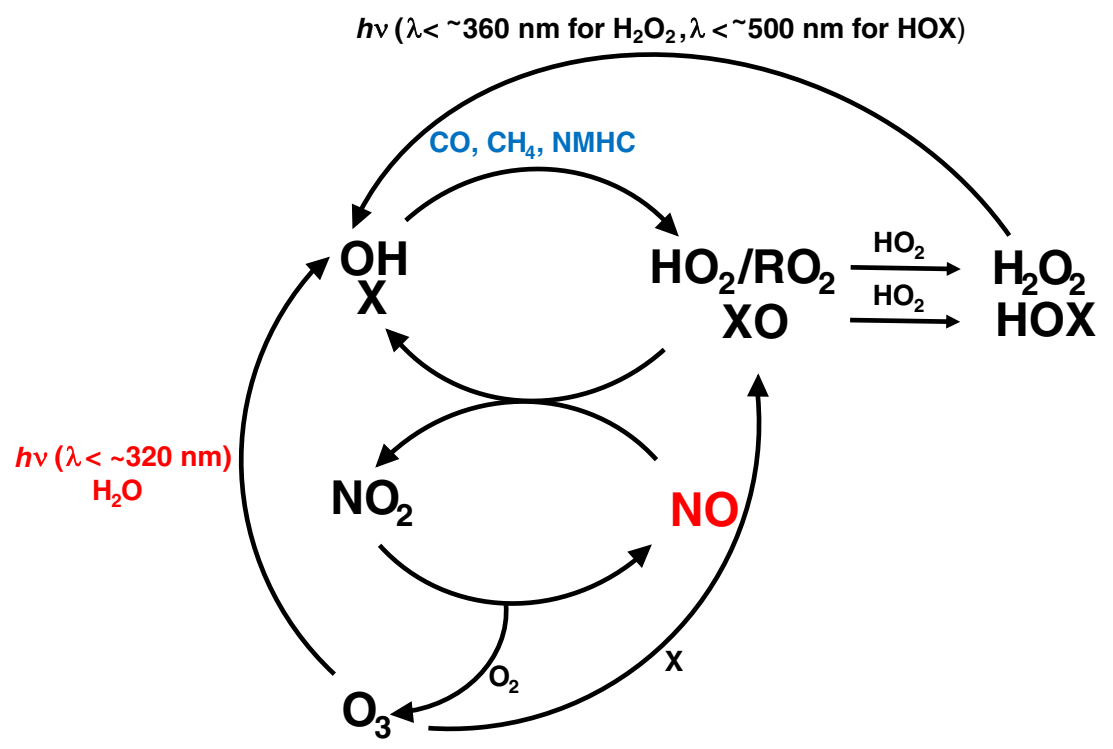

emissions of $\mathrm{NO}_{x}$ and reduced carbon gases, $\mathrm{O}_{3}$ concentrations have increased over the twentieth century $[2,3]$, while global $\mathrm{OH} \cdot$ concentrations are thought to have remained relatively stable, at least for the last 30 years [4]. The relative stability of $\mathrm{OH} \cdot$ is due to the buffering effect of simultaneous increases in anthropogenic $\mathrm{OH} \cdot$ sources $\left(\mathrm{NO}_{x}\right)$ and sinks (reduced carbon gases) [5].

The response of $\mathrm{OH}$ to the current and future warming climate resulting from increases in anthropogenic greenhouse gases is unclear due to competing effects. $\mathrm{OH} \cdot$ may increase in a future, warmer world due to increases in water vapor abundance and in convection and thus lightning $\mathrm{NO}_{x}$ $[6,7]$. On the other hand, $\mathrm{OH} \cdot$ may decrease due to increases in temperature-dependent emissions of biogenic hydrocarbons and rate constants for $\mathrm{OH} \cdot$-destruction reactions [8]. Anthropogenic land use change could also perturb biogenic emissions, with consequences for $\mathrm{OH}$ [9]. $\mathrm{OH} \cdot$ would also be sensitive to changes in stratospheric $\mathrm{O}_{3}$ due to its influence on ultraviolet (UV)-induced photochemical reactions in the troposphere [10].

Projections of the response of the tropospheric oxidative capacity to future change have typically relied on threedimensional chemistry-climate modeling frameworks (e.g., Naik et al. [11]). Future scenarios of greenhouse gases and anthropogenic land use change are applied to these models, together with emissions scenarios of short-lived gases and aerosols of importance to $\mathrm{OH} \cdot$ and other oxidants. Many future scenarios have been developed with support of the Intergovernmental Panel on Climate Change (IPCC) [12] and have permitted cross-model comparison, thus deepening our awareness of uncertainties in model assumptions and processes. To date, these cross-model comparisons have revealed large discrepancies in projections of future oxidative capacity (e.g., Voulgarakis et al. [13]).
One solution for dealing with uncertainties in future model predictions is to look to the past as an analogue. Future changes in oxidant abundances will likely be very different from what occurred in the past due to different or even opposite forcings. For example, past climates are characterized by minimal anthropogenic impacts and, for the last $\sim 100,000$ years, cooler temperatures. However, knowledge of past variability in tropospheric oxidants can provide information on the sensitivity of tropospheric oxidant abundance over a variety of time scales, and thus inform potential future changes. Here, we review current knowledge of the oxidation capacity of the atmosphere from the paleo-perspective, focusing on both observational constraints and modeling results. This review is followed by a discussion of the implications of what we have learned from the paleo-perspective for understanding the key uncertainties and for informing estimates of possible future changes in the oxidizing capacity of the atmosphere. We end by discussing the most promising future directions for improving our understanding of potential changes in the oxidative capacity of the atmosphere.

\section{A Paleo-Perspective on Changes in the Oxidation Capacity of the Atmosphere}

\section{Paleo Observations}

Polar ice-core measurements of long-lived greenhouse gases such as carbon dioxide $\left(\mathrm{CO}_{2}\right)$ and $\mathrm{CH}_{4}$ and aerosols such as sulfate and nitrate provide evidence of the extent and degree of human influence on the chemical composition of the atmosphere. Anthropogenic activities, such as the burning of fossil fuels, have increased the concentration of $\mathrm{CO}_{2}$ and $\mathrm{CH}_{4}$ by 43 and $150 \%$, respectively [14-16]. Concentrations of $\mathrm{CO}_{2}$ and 
$\mathrm{CH}_{4}$ during the Last Glacial Maximum (LGM) were $30 \%$ and $40-50 \%$ of their preindustrial values, respectively [17-19]. Aerosol concentrations from Greenland ice cores for the 1970-1990s show increases in nitrate of $\sim 100 \%$ and in sulfate of $320 \%$ since the preindustrial era, demonstrating the impacts of fossil fuel burning [20,21]. Greenland ice-core nitrate and sulfate concentrations have leveled off or declined since 1990 due to emissions reductions in the USA [22]. In contrast, continued increases in sulfate concentrations over the past 50years as observed in a Tibetan ice core [23] are consistent with increasing trends in Asian emissions of $\mathrm{SO}_{2}$ [22]. The lack of similar increases in Antarctic ice cores [24] shows that anthropogenic influence on aerosol abundance is by far most important in the Northern Hemisphere. Oxidants such as $\mathrm{OH} \cdot$ and $\mathrm{O}_{3}$, however, are not directly preserved in ice cores, so much less is known about how human activity has influenced their abundances. Here, we briefly review potential proxies for tropospheric oxidants. Table 1 provides a summary of the observational constraints on changes in oxidant abundances in the present day and LGM relative to the preindustrial Holocene, based on proxies that are thought to be well-preserved during the time scale of interest as discussed below.

Ozone

In the late nineteenth century, $\mathrm{O}_{3}$ abundance was measured around the world using either the Schönbein method (e.g., [25]) or a wet-chemical method involving the oxidation of arsenite in neutral aqueous solution [26]. The Schönbein method employs paper strips impregnated with potassium iodide and starch and is sensitive to artefacts from humidity and other oxidants [26,27]. The arsenite method is also subject to both positive artefacts from other oxidants such as $\mathrm{H}_{2} \mathrm{O}_{2}$ and negative artefacts from reducing gases such as $\mathrm{SO}_{2}$ [26]. Volz and Kley [26] reproduced and recalibrated the most reliable of the nineteenth-century observations, those from Paris from 1876-1910 [2]. Their work suggests very low preindustrial surface $\mathrm{O}_{3}$ concentrations on the order of $10 \mathrm{ppbv}$, implying a doubling of background surface $\mathrm{O}_{3}$ abundance in rural areas over this 100-year period [26]. Although the accuracy of these nineteenth-century observations has been debated [28, 46], they suggest at least a factor of 2-3 increase in surface $\mathrm{O}_{3}$ in the late twentieth century, compared to its preindustrial abundance [2].

\section{Hydrogen Peroxide}

Hydrogen peroxide $\left(\mathrm{H}_{2} \mathrm{O}_{2}\right)$ is the only oxidant that can be directly measured in polar ice cores and was first measured in both Greenland and Antarctic ice by Neftel et al. [47]. Hydrogen peroxide forms through the self-reaction of $\mathrm{HO}_{2}$, which in turn is formed through the oxidation of reduced trace gases such as $\mathrm{CO}$ and $\mathrm{CH}_{4}$ by $\mathrm{OH} \cdot$. Once formed, $\mathrm{H}_{2} \mathrm{O}_{2}$ has an

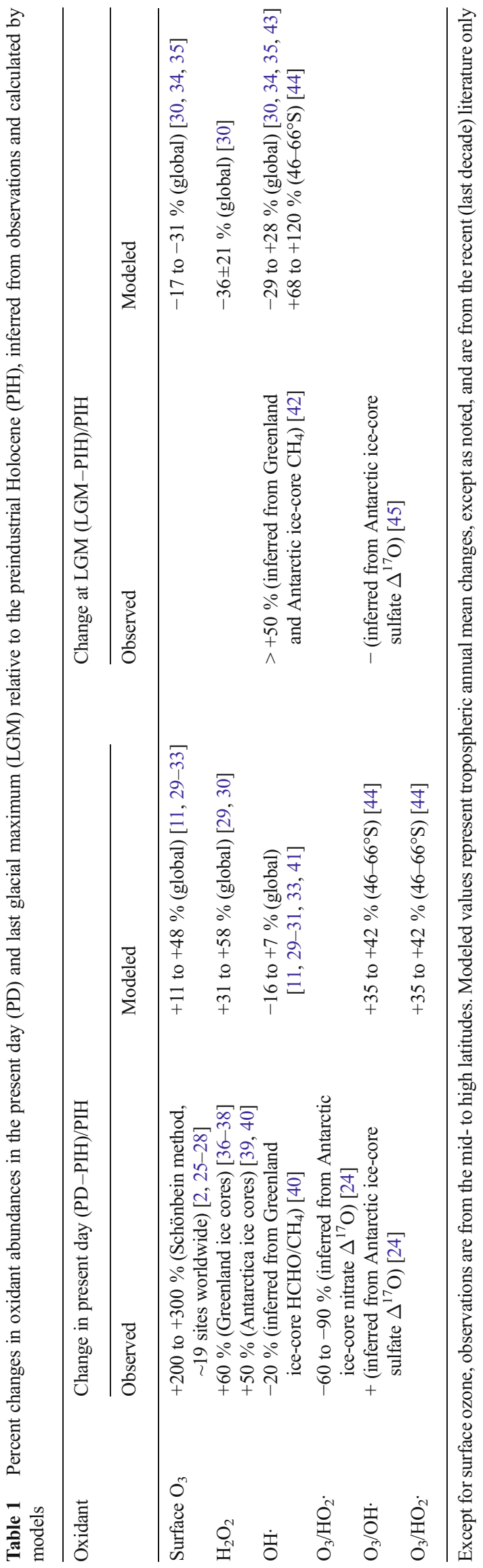


atmospheric lifetime of a few days and is lost from the atmosphere via photolysis, chemical reactions in the gas- (e.g., $\mathrm{H}_{2} \mathrm{O}_{2}+\mathrm{OH} \cdot$ ) and aqueous-phase (e.g., $\mathrm{HSO}_{3}{ }^{-}+\mathrm{H}_{2} \mathrm{O}_{2}$ ), and wet and dry deposition to the Earth's surface. $\mathrm{H}_{2} \mathrm{O}_{2}$ is reversibly deposited to snow, meaning it can evaporate back into the overlying atmosphere $[48,49]$ or undergo ultraviolet (UV)induced destruction (photolysis) [50, 51] and production [52, 53]. Dust may also catalyze $\mathrm{H}_{2} \mathrm{O}_{2}$ decomposition in the ice at depth [54]. This so-called post-depositional processing complicates interpretation of ice-core $\mathrm{H}_{2} \mathrm{O}_{2}$ concentrations. Frey et al. [55] suggest that variability in ice-core $\mathrm{H}_{2} \mathrm{O}_{2}$ concentrations may represent atmospheric variability only under conditions of relatively stable temperatures and UV radiation at locations with low temperatures $\left(<-31^{\circ} \mathrm{C}\right)$ and high snow accumulation rates $\left(>30 \mathrm{~cm} \mathrm{year}^{-1}\right)$.

$\mathrm{H}_{2} \mathrm{O}_{2}$ measurements from Greenland and Antarctic ice cores show 50-60\% increase over the past 100-200 years, with most of that increase occurring since the early 1970 s [36-40]. Möller [56] interprets most of the variability in the Greenland record to a changing sink from aqueous-phase reaction of $\mathrm{H}_{2} \mathrm{O}_{2}$ with dissolved $\mathrm{SO}_{2}\left(\mathrm{HSO}_{3}{ }^{-}\right)$from coal combustion, with a slight decrease in $\mathrm{H}_{2} \mathrm{O}_{2}$ from 1850-1970 as $\mathrm{SO}_{2}$ anthropogenic emissions rose [22]. Implementation of the Clean Air Act of 1970 and its amendments led to a decline in $\mathrm{SO}_{2}$ emissions and a subsequent increase in $\mathrm{H}_{2} \mathrm{O}_{2}$. In contrast, the increase in Antarctic ice-core $\mathrm{H}_{2} \mathrm{O}_{2}$ is thought to be driven by an increase in local, tropospheric photolysis rates resulting from decreases in overhead (stratospheric) $\mathrm{O}_{3}$-column abundance, with a smaller but significant impact from surface $\mathrm{O}_{3}$ abundance [39].

\section{The Isotopes of $\mathrm{CH}_{4}$}

$\mathrm{CH}_{4}$ is well-preserved in gas bubbles in ice cores, providing a rich history of its atmospheric abundance in the past. The main natural source of $\mathrm{CH}_{4}$ is from wetlands, with smaller sources from ruminants, termites, thermokarst lakes, and biomass burning [57]. Major anthropogenic sources are from fossilfuel extraction, agriculture (primarily rice), ruminant livestock, and waste treatment [57]. The main ( $\sim 85 \%)$ sink for $\mathrm{CH}_{4}$ in the troposphere is oxidation by $\mathrm{OH} \cdot$ [57]. Minor sinks include oxidation in the stratosphere and in soils $[57,58]$. The carbon and hydrogen isotopic composition of $\mathrm{CH}_{4}$ is determined by its relative source strengths, as different sources have different isotopic signatures, and the strength of its sinks, which all act to enrich the isotopic composition of remaining atmospheric $\mathrm{CH}_{4}$. Oxidation of $\mathrm{CH}_{4}$ by $\mathrm{OH} \cdot$ leads to large enrichments in the hydrogen isotopes $(\delta \mathrm{D})$ on the order of $200 \%$ 0 59,60$]$ and smaller enrichments in the carbon isotopes $\left(\delta^{13} \mathrm{C}\right)$ on the order of $4-5 \%[60,61]$ relative to what was emitted. Although tropospheric $\mathrm{Cl}$ - is thought to be only a minor sink (3-4\%) for $\mathrm{CH}_{4}[57,62,63]$, it induces an isotopic fractionation more than an order of magnitude larger than does reaction with $\mathrm{OH} \cdot[64,65]$. The small soil sink (5\% [57]) of $\mathrm{CH}_{4}$ induces an isotopic fractionation about four times larger than the $\mathrm{OH} \cdot \operatorname{sink}[66,67]$.

As with ice-core $\mathrm{CH}_{4}$ (e.g., Chappellaz et al. [68]), the observed variability in $\mathrm{CH}_{4}$ isotopes from Craig et al. [69], and many subsequent analyses were interpreted by assuming a constant sink of $\mathrm{CH}_{4}$ or by making a priori assumptions about changes in the sink strength [14, 70-78]. Fischer et al. [79], however, determined that the most likely explanation for the observed increase in $\delta^{13} \mathrm{C}\left(\mathrm{CH}_{4}\right)$ and $\delta \mathrm{D}\left(\mathrm{CH}_{4}\right)$ in the LGM compared to the preindustrial Holocene was a significantly reduced ( $>50 \%)$ atmospheric lifetime of $\mathrm{CH}_{4}$ in the LGM. Though a unique interpretation of ice-core methane isotope records is not possible [73], simultaneous measurements of ${ }^{13} \mathrm{C} /{ }^{12} \mathrm{C}$ and $\mathrm{D} / \mathrm{H}$ of $\mathrm{CH}_{4}$ may be used to examine possible scenarios and place bounds on past $[72,80]$ and present $[81$, 82] variability in the relative importance of the $\mathrm{OH} \cdot$ sink.

\section{Formaldehyde}

Formaldehyde (HCHO) is an oxidation product of the $\mathrm{CH}_{4}+$ $\mathrm{OH} \cdot$ reaction, and in remote, unforested regions, the main source of $\mathrm{HCHO}$ is from oxidation of $\mathrm{CH}_{4}$ by $\mathrm{OH}$. $\mathrm{HCHO}$ is lost from the atmosphere via photolysis and oxidation by $\mathrm{OH} \cdot$. Due to interactions between $\mathrm{CH}_{4}, \mathrm{HCHO}$, and $\mathrm{OH} \cdot$, the $\mathrm{HCHO} / \mathrm{CH}_{4}$ ratio in ice cores could potentially serve as a proxy for past $\mathrm{OH}$ abundance, with higher values indicating higher $\mathrm{OH} \cdot$ [42]. Like $\mathrm{H}_{2} \mathrm{O}_{2}$, $\mathrm{HCHO}$ is reversibly deposited to ice sheets via evaporation [83] and photochemical loss [84], hindering its interpretation in terms of past atmospheric abundance. Assuming that the transfer of $\mathrm{HCHO}$ between the snow/ice and the overlying atmosphere was constant over time, observations of $\mathrm{HCHO} / \mathrm{CH}_{4}$ from Greenland snow and firn suggest that $\mathrm{OH} \cdot$ was $30 \%$ higher in the preindustrial, qualitatively consistent with $\mathrm{HCHO}$ observations from Law Dome, Antarctica [40]. HCHO observations from a South Greenland and Antarctic (Byrd) ice core imply, in turn, that $\mathrm{OH} \cdot$ was a factor of 2-4 lower in the LGM relative to the preindustrial [42]. In contrast, ice cores from central Greenland (Summit) [38] and Antarctica (Law Dome) [40] show higher $\mathrm{HCHO}$ concentrations in the last glacial period, with $\mathrm{HCHO}$ variability at Summit paralleling that of calcium $\left(\mathrm{Ca}^{2+}\right)$. However, the large change in snow accumulation rates in Antarctica and Greenland on the glacial-interglacial time scale likely precludes constant preservation of $\mathrm{HCHO}$.

\section{Nitrate Concentration and Its Nitrogen Isotopes}

Nitrate $\left(\mathrm{NO}_{3}{ }^{-}\right)$is a major sink for atmospheric $\mathrm{NO}_{x}$ and its concentration in ice cores can provide insight into past variability in $\mathrm{NO}_{x}$ concentrations. Since $\mathrm{NO}_{x}$ plays an important role in the formation and cycling of tropospheric oxidants (Fig. 1), information about its past variability can 
shed light on the oxidation capacity of paleo atmospheres. The atmospheric lifetime of $\mathrm{NO}_{x}$ against oxidation to nitrate is on the order of 1 day [85], and the atmospheric lifetime of nitrate is on the order of 3-4 days, making polar ice-core nitrate concentrations an indicator of mid- to highlatitude atmospheric variability. The $(83 \pm 34) \%$ increase in Greenland ice-core nitrate concentrations [20] is smaller than the $\sim 150 \%$ increase in fossil-fuel $\mathrm{NO}_{x}$ emissions between 1940-1970 from North America [86], the main aerosol source region to Summit, Greenland. The difference is likely due to some depositional loss of nitrate to the surface during transport and possibly also in part due to postdepositional loss from the Greenland snowpack (see below). The lack of a similar increase in nitrate concentrations in a West Antarctic ice core [24] suggests little change in $\mathrm{NO}_{x}$ abundance in the mid- to high-southern latitudes due to anthropogenic activities. Antarctic ice-core records show higher nitrate concentrations in the glacial period relative to the preindustrial Holocene [87, 88], while Greenland ice-core records snow little glacial-interglacial variability $[89,90]$.

The interpretation of ice-core nitrate concentration records during times of major climate change has been hampered by the influence of post-depositional processing of snow nitrate. Snow nitrate is lost via evaporation [91] and photolysis [92] and the degree of post-depositional loss is determined mainly by the snow accumulation rate and the concentration of UVabsorbing impurities in the snow [93, 94]. Higher snow accumulation rates lead to less post-depositional loss by more quickly burying snow nitrate below the photic zone. During periods when the snow accumulation rate and the concentration of UV-absorbing snow impurities have not changed significantly, such as over the past several hundreds [95] to several thousands [24] of years, variability in ice-core nitrate concentrations likely represents atmospheric variability of nitrate and $\mathrm{NO}_{x}$. However, during periods of major changes in snow accumulation rate, such as over glacial-interglacial cycles, variability in ice-core nitrate concentrations may not reflect its past atmospheric abundance.

The photolysis of snowpack nitrate induces a large fractionation on its nitrogen isotopes $\left.\left(\delta^{15} \mathrm{~N}_{\left(\mathrm{NO}_{3}\right.}{ }^{-}\right)\right)$on the order of $50 \%$, emitting isotopically light $\mathrm{NO}_{x}$ into the overlying boundary layer and leaving the nitrate remaining in the snow enriched in $\delta^{15} \mathrm{~N}$ by up to $350 \%$ [94, 96, 97]. As the enrichment in ice-core $\delta^{15} \mathrm{~N}\left(\mathrm{NO}_{3}{ }^{-}\right)$is proportional to the fraction of nitrate lost from the snow due to photolysis, simultaneous measurement of ice-core nitrate concentrations and $\delta^{15} \mathrm{~N}\left(\mathrm{NO}_{3}{ }^{-}\right)$may allow for a semi-quantitative reconstruction of atmospheric nitrate concentrations. Such a reconstruction may be feasible in regions such as across much of the East Antarctic plateau where snow accumulation rates are low and the variability in $\left.\delta^{15} \mathrm{~N} \mathrm{NO}_{3}{ }^{-}\right)$is driven mainly by photolytic loss $[93,94]$.

\section{Oxygen Isotopes of Sulfate and Nitrate}

The mass-independent fractionation evident in atmospheric $\mathrm{O}_{3}$ affects the oxygen isotopic composition $\left(\Delta^{17} \mathrm{O}=\delta^{17} \mathrm{O}-\right.$ $0.52 \times \delta^{18} \mathrm{O}$ ) of nitrate and sulfate in the atmosphere and provides a tool to assess their formation pathways. $\mathrm{O}_{3}$ dominated reactions lead to high $\Delta^{17} \mathrm{O}$ values in the nitrate and sulfate products, while reactions dominated by $\mathrm{HO}_{x}$ $\left(\mathrm{OH} \cdot \mathrm{HO}_{2} \cdot+\mathrm{RO}_{2}\right.$, or $\left.\mathrm{H}_{2} \mathrm{O}_{2}\right)$ lead to low $\Delta^{17} \mathrm{O}$. The value of $\Delta^{17} \mathrm{O}$ in nitrate and sulfate from ice cores can thus provide information on the relative abundance of $\mathrm{O}_{3} / \mathrm{HO}_{x}$ in paleo atmospheres.

Nitrate formation occurs via oxidation of $\mathrm{NO}_{x}$ by $\mathrm{HO}_{x}$ and $\mathrm{O}_{3}$. The $\Delta^{17} \mathrm{O}$ of $\mathrm{NO}_{x}$ is determined by the relative abundance of $\mathrm{O}_{3} /\left(\mathrm{HO}_{2} \cdot+\mathrm{RO}_{2} \cdot\right)$ during $\mathrm{NO}_{x}$ cycling reactions, while the $\Delta^{17} \mathrm{O}$ of nitrate $\left(\Delta^{17} \mathrm{O}\left(\mathrm{NO}_{3}{ }^{-}\right)\right)$is determined by the $\Delta^{17} \mathrm{O}$ of $\mathrm{NO}_{2}$ and the oxidant $\left(\mathrm{OH}\right.$ or $\mathrm{O}_{3}$ ) involved in the oxidation of $\mathrm{NO}_{2}$ to $\mathrm{HNO}_{3}$ [98]. Since $\Delta^{17} \mathrm{O}\left(\mathrm{NO}_{3}{ }^{-}\right)$is most sensitive to the $\Delta^{17} \mathrm{O}$ of $\mathrm{NO}_{2}$, the variability of $\Delta^{17} \mathrm{O}\left(\mathrm{NO}_{3}{ }^{-}\right)$can to first order be interpreted as variability in the relative $\mathrm{O}_{3} /\left(\mathrm{HO}_{2} \cdot+\mathrm{RO}_{2} \cdot\right)$ abundance.

Photolytic-driven loss of snow nitrate itself does not directly impact $\Delta^{17} \mathrm{O}\left(\mathrm{NO}_{3}{ }^{-}\right)$since it involves mass-dependent isotopic behavior. However, some of the snow-sourced $\mathrm{NO}_{x}$ is reoxidized and re-deposited to the snowpack, and this recycling tends to erase the oxidant signature in $\Delta^{17} \mathrm{O}\left(\mathrm{NO}_{3}{ }^{-}\right)$derived from the primary $\mathrm{NO}_{x}$-source regions, replacing it with a local oxidant signature. In regions of low snow accumulation rates and high photolytic-driven recycling such as the East Antarctic plateau, ice-core $\Delta^{17} \mathrm{O}\left(\mathrm{NO}_{3}{ }^{-}\right)$measurements [94] likely indicate a local oxidant signature. In West Antarctica and Greenland, where snow accumulation rates are higher, the oxidant signature from the primary $\mathrm{NO}_{\mathrm{x}}$-source regions is more likely preserved $[24,99]$.

Ice-core $\Delta^{17} \mathrm{O}\left(\mathrm{NO}_{3}{ }^{-}\right)$measurements from a Greenland ice core indicate a peak in $\Delta^{17} \mathrm{O}\left(\mathrm{NO}_{3}{ }^{-}\right)$beginning in the mid-1800s and ending in the early 1900s [100]. This peak coincided with indicators of biomass burning records from a Greenland ice core [101], suggesting that biomass burning in North America increased the relative abundance of $\mathrm{O}_{3}$ over $\left(\mathrm{HO}_{2} \cdot+\mathrm{RO}_{2} \cdot\right)$ in that region. In contrast, a 2400 year ice-core record from West Antarctica shows a gradual decrease in $\Delta^{17} \mathrm{O}\left(\mathrm{NO}_{3}{ }^{-}\right)$over most of the record, with a more rapid decrease between the mid-nineteenth century and the present day [24]. The long-term gradual decrease in $\Delta^{17} \mathrm{O}\left(\mathrm{NO}_{3}{ }^{-}\right)$is likely due to an increase in the amount of photolytic-driven recycling, consistent with a decrease in snow accumulation rate over this same time period. The rapid recent decrease in $\Delta^{17} \mathrm{O}\left(\mathrm{NO}_{3}{ }^{-}\right)$over the last 150 years may be due to the estimated $60-90 \%$ decrease in the $\mathrm{O}_{3} /$ $\left(\mathrm{HO}_{2} \cdot+\mathrm{RO}_{2} \cdot\right)$ ratio in the extratropical Southern Hemisphere, when anthropogenic activities increased the sum of $\left(\mathrm{HO}_{2} \cdot+\mathrm{RO}_{2} \cdot\right)$ more rapidly than $\mathrm{O}_{3}$. 
Sulfate formation occurs via oxidation of $\mathrm{SO}_{2}$ in the gasphase through oxidation by $\mathrm{OH} \cdot$ and in cloud droplets by $\mathrm{H}_{2} \mathrm{O}_{2}$ and $\mathrm{O}_{3}$. Due to its atmospheric lifetime of 5-6 days [102], ice-core $\Delta^{17} \mathrm{O}\left(\mathrm{SO}_{4}{ }^{2-}\right)$ measurements can provide information about the mid- to high-latitude atmosphere. Unlike nitrate, sulfate does not undergo post-depositional processing and both its concentration and isotopic composition are wellpreserved throughout the ice-core record. Variability in the relative abundance of the oxidants $\mathrm{OH} \cdot \mathrm{H}_{2} \mathrm{O}_{2}$, and $\mathrm{O}_{3}$ influences $\Delta^{17} \mathrm{O}\left(\mathrm{SO}_{4}{ }^{2-}\right)$ [29] because each oxidant possesses a unique $\Delta^{17} \mathrm{O}$ value that is transferred to sulfate during its formation [103]. However, clouds also affect $\Delta^{17} \mathrm{O}\left(\mathrm{SO}_{4}{ }^{2-}\right)$ by influencing the relative importance of gas- versus aqueous-phase production. In addition, as the oxidation rate of dissolved $\mathrm{SO}_{2}$ by $\mathrm{O}_{3}$ is highly $\mathrm{pH}$ dependent, cloud $\mathrm{pH}$ determines the relative importance of $\mathrm{O}_{3}$ versus $\mathrm{H}_{2} \mathrm{O}_{2}$ oxidation.

In their analysis of a West Antarctic ice core, Sofen et al. [24] detected a step increase in $\Delta^{17} \mathrm{O}\left(\mathrm{SO}_{4}{ }^{2-}\right)$ of $1.1 \%$ in the early nineteenth century, a time when no significant change in climate, ice-core $\mathrm{pH}$, and sulfate and $\mathrm{H}_{2} \mathrm{O}_{2}$ concentrations occurred. The cause of the increase is unclear [24].

Alexander et al. [100] analyzed oxygen isotopes in a Greenland ice core and found a peak in both $\Delta^{17} \mathrm{O}\left(\mathrm{SO}_{4}{ }^{2-}\right)$ and $\Delta^{17} \mathrm{O}\left(\mathrm{NO}_{3}{ }^{-}\right)$beginning in the mid-1800s and ending in the early 1900s. This peak coincided with indicators of biomass burning [101], suggesting that enhanced $\mathrm{O}_{3}$ from agricultural clearing in North America increased the importance of $\mathrm{O}_{3}$ oxidation of $\mathrm{SO}_{2}$ and $\mathrm{NO}_{x}$. In addition, $\Delta^{17} \mathrm{O}\left(\mathrm{SO}_{4}{ }^{2-}\right)$ values in 1980 were slightly higher than values before 1800 , implying an increased importance for $\mathrm{O}_{3}$ oxidation in the industrial era compared to preindustrial times.

Discrete measurements of $\Delta^{17} \mathrm{O}\left(\mathrm{SO}_{4}{ }^{2-}\right)$ from an East Antarctic ice core (Vostok) over a full glacial-interglacial cycle ( $\sim 130 \mathrm{kyr}$ before present) show significantly lower values during the glacial period compared to the interglacial periods before and after [45]. The observed variability in $\Delta^{17} \mathrm{O}\left(\mathrm{SO}_{4}{ }^{2}\right.$ ${ }^{-}$) was interpreted to be driven by a $40 \%$ increase in the amount of sulfate formed by $\mathrm{OH} \cdot$ oxidation relative to $\mathrm{O}_{3}$ oxidation. However, the role of cloud fraction and liquid water content in driving the observed variability in $\Delta^{17} \mathrm{O}\left(\mathrm{SO}_{4}{ }^{2-}\right)$ on this time scale could not be discerned with available observations.

\section{Oxygen Isotopes of Carbon Monoxide}

Carbon monoxide (CO) originates from incomplete combustion of fossil fuels and biomass and from the oxidation of reduced carbon gases such as $\mathrm{CH}_{4}$ and biogenic hydrocarbons [104]. Its tropospheric lifetime of $\sim 2$ months is determined by $\mathrm{OH} \cdot$ oxidation [105]. CO serves as the largest (70\% [106]) sink of $\mathrm{OH} \cdot$ and is an $\mathrm{O}_{3}$ precursor, rendering its abundance an important control on the oxidation capacity of the atmosphere.
Similar to the long-lived greenhouse gases $\mathrm{CO}_{2}$ and $\mathrm{CH}_{4}, \mathrm{CO}$ is preserved in air bubbles in ice cores. In situ production of CO in Greenland ice cores has been observed [107] and is thought to originate from photo-oxidation of organic material [107-109], complicating the reconstruction of past $\mathrm{CO}$ in the Northern Hemisphere. Alternative explanations for in situ CO production involve the influence of cosmic rays [110] or microbial activity [107]. In situ CO production in Antarctic snow and ice is thought to be minimal in part due to much lower concentrations of organic material [111]. Antarctic firn and ice-core observations of $\mathrm{CO}$ abundance since $250 \mathrm{BC}$ show century-long trends that may reflect changes in biomassburning sources [e.g., 60, 105]. Isotopic measurements of $\delta^{18} \mathrm{O}(\mathrm{CO})$ and $\delta^{13} \mathrm{C}(\mathrm{CO})$ are consistent with this interpretation $[111,112]$, as these isotopic signatures are determined in part by $\mathrm{CO}$ sources. $\Delta^{17} \mathrm{O}(\mathrm{CO})$ is mainly influenced by its degree of reaction with $\mathrm{OH} \cdot[113,114] . \Delta^{17} \mathrm{O}(\mathrm{CO})$ has not yet been measured in ice cores, but its dependence on $\mathrm{OH}$ - abundance and its preservation in Antarctic ice renders it a potential proxy for the oxidation capacity of paleo atmospheres [115].

\section{Models}

Table 1 summarizes model estimates of the changes in oxidant abundances in the present day and LGM relative to the preindustrial Holocene published within the last decade [11, 29-35, $41,43,44,116]$. A complete list of all model results to date, except for the recent results of Achakulwisut et al. [44] and John et al. [116], are in Murray et al. [30]. Differences between models are due mainly to differences in assumptions about past emissions and climate and are also sensitive to assumptions about $\mathrm{HO}_{x}$ recycling during isoprene oxidation [44, 117].

Table 1 reveals that there is no model consensus on the sign of the change in $\mathrm{OH} \cdot$ in the LGM or the present day, relative to the preindustrial. Most models calculate decreases or no change in present day $\mathrm{OH} \cdot$ relative to the preindustrial due to increases in $\mathrm{OH} \cdot$ sinks $\left(\mathrm{CO}\right.$ and $\left.\mathrm{CH}_{4}\right)$ that are partly or completely compensated by increases in $\mathrm{NO}_{x}$ emissions. All models calculate an increase in present day $\mathrm{O}_{3}$ and $\mathrm{H}_{2} \mathrm{O}_{2}[11$, 29-33, 41]. Modeled increases in $\mathrm{O}_{3}$ are much smaller than the Schönbein measurements [2, 25-28] suggest because the models cannot reproduce the low preindustrial $\mathrm{O}_{3}$ abundance. Parrella et al. [32] show that inclusion of bromine chemistry in model calculations lowers preindustrial $\mathrm{O}_{3}$ to be more in line with the Schönbein observations, though the directional impact of reactive bromine on tropospheric $\mathrm{O}_{3}$ abundance depends on assumptions in the chemical mechanism [118]. Modeled decreases in present day $\mathrm{OH} \cdot[11,29,31,33,116]$ are smaller than the Greenland $\mathrm{HCHO} / \mathrm{CH}_{4}$ observations imply [40]. Modeled increases in present-day $\mathrm{H}_{2} \mathrm{O}_{2}[29,30]$ are similar to those in the Greenland and Antarctic observations [36-40]. Modeled changes in the $\mathrm{O}_{3} / \mathrm{OH} \cdot$ ratio over the 
Southern Ocean $[30,44]$ are qualitatively consistent with icecore observations of sulfate $\Delta^{17} \mathrm{O}$ [24]. Finally, modeled changes in the $\mathrm{O}_{3} / \mathrm{HO}_{2} \cdot$ ratio over South America [44] are in the right direction but much smaller than nitrate $\Delta^{17} \mathrm{O}$ observations suggest [24].

Modeled LGM OH· abundances tend to be higher than in the preindustrial Holocene [34, 35, 43], though the modeled increases are much smaller than the ice-core $\mathrm{CH}_{4}$ isotopes suggest [79]. Modeled LGM increases in $\mathrm{OH} \cdot$ and decreases in $\mathrm{O}_{3}$ over the Southern Ocean $[30,44]$ are qualitatively consistent with ice-core sulfate $\Delta^{17} \mathrm{O}$ observations [45].

\section{Implications for the Future}

\section{Drivers of Change in the Oxidative Capacity of the Future Atmosphere}

The drivers of the oxidative capacity of the troposphere will likely change in future decades. Warmer surface temperatures will enhance evaporation, thereby increasing water vapor and $\mathrm{OH} \cdot$ production [119]. Lightning frequency will also change, but the sign and magnitude of that change are uncertain, since convection depends not just on moisture content but also the vertical temperature gradient [120]. Greenhouse gas cooling in the lower stratosphere could accelerate the Brewer-Dobson circulation, reducing the overhead $\mathrm{O}_{3}$ column in the tropics but thickening the column over the extra-tropics [121]. Future changes in ozone-depleting substances will also impact the stratospheric $\mathrm{O}_{3}$ abundance [122]. Such changes in overhead $\mathrm{O}_{3}$ would influence tropospheric photolysis rates as well as the stratospheric flux of $\mathrm{O}_{3}$ into mid-latitudes. Changes in aerosol abundance resulting from changing emissions of aerosol precursors or lifetimes will also impact oxidants through heterogeneous reactions of $\mathrm{N}_{2} \mathrm{O}_{5}[123]$ and $\mathrm{HO}_{2}[124]$ on their surface.

Changes in the biosphere will also perturb the oxidative capacity. Widespread deforestation could affect oxidants by disrupting the hydrological cycle and reducing biogenic emissions [9, 125]. Warmer temperatures, on the other hand, will enhance biogenic emissions, though the effect of increasing $\mathrm{CO}_{2}$ on plant physiology may modulate that increase [126]. Wetland and peatland emissions of methane are likely to rise as microbial activity accelerates in a warming climate, and such trends may already be occurring [127]. Depending on the ecosystem and local meteorology, wildfire frequency could increase in future decades, enhancing emissions of $\mathrm{CO}$, hydrocarbons, and $\mathrm{NO}_{x}[128]$.

Finally, trends in the anthropogenic emissions of $\mathrm{O}_{3}$ and aerosol precursors could have large effects on the oxidative capacity. Future scenarios of precursor emissions have been devised to probe the response of atmospheric composition to trends in human activity. For example, the Representative
Concentration Pathway (RCP) scenarios were designed to achieve the radiative forcing targets of 2.6, 4.5, 6.0, and $8.5 \mathrm{~W} \mathrm{~m}^{-2}$ by 2100 and have been designated RCP2.6, $\mathrm{RCP} 4.5, \mathrm{RCP} 6.0$, and RCP8.5, respectively [12]. In all RCP scenarios, global anthropogenic $\mathrm{NO}_{x}$ emissions decline 30 $50 \%$ over the course of the twenty-first century. Trends in global anthropogenic hydrocarbon and $\mathrm{CO}$ emissions are flat during the 2000-2050 time range, and then also show declines by $30-50 \%$ by 2100 . While the global methane burden for three of the RCP scenarios decreases by 2100 , RCP8.5 projects a doubling of the methane over the century. Finally, in all scenarios, concentrations of chlorofluorocarbons and other $\mathrm{O}_{3}$-depleting substances in the stratosphere decrease substantially over the twenty-first century.

\section{Tests of Modeled Oxidative Capacity over the 1980-2010 Timeframe}

Multi-model time slice simulations conducted in support of the Atmospheric Chemistry Climate Model Intercomparison Project (ACCMIP) for 1980 and 2000 were analyzed to test our understanding of the impact of climate change and anthropogenic emissions on the oxidative capacity of the atmosphere [11]. Results from this multi-model study can be compared to the $\mathrm{OH} \cdot$ global abundance inferred from observations of methyl chloroform, a trace gas whose main sink is tropospheric $\mathrm{OH}$. The models suggest that global $\mathrm{OH} \cdot$ has increased 3.5 $\pm 2.2 \%$ since 1980 , mainly due to increasing $\mathrm{NO}_{x}$ emissions. Observations, however, imply a possible decrease in global mean $\mathrm{OH} \cdot$ in the 1980-2000 timeframe [129, 130], with little trend thereafter [4]. Comparison of the modeled interhemispheric ratios $(\mathrm{N} / \mathrm{S})$ of tropospheric mean $\mathrm{OH} \cdot$ to that inferred from observations reveals another discrepancy, with models calculating an average N/S ratio of 1.28 and observationderived ratios ranging between $0.85-1.0[11,131]$. These spatial and temporal discrepancies between modeled and inferred $\mathrm{OH} \cdot$ may arise from model underestimates of $\mathrm{CO}$ concentrations in the Northern Hemisphere, incomplete understanding of the photochemistry of biogenic species, or neglect of the heterogeneous uptake of $\mathrm{HO}_{2}$. on aerosols $[11,44]$.

\section{Projections of the Oxidative Capacity in the Twenty-First Century}

Model studies have been extended beyond 2000 in an effort to characterize the effects of changing climate and emissions on the tropospheric oxidative capacity. Such studies indicate that climate change alone could increase global mean $\mathrm{OH} \cdot$ by 4 $13 \%$ by 2050 mainly because of higher water vapor abundance and increased lightning $\mathrm{NO}_{x}$ frequency (Wu et al. [119], and references therein). Most of these studies, however, did not consider the effect of increased methane emissions from 
wetlands and peatlands, which could be appreciable [132] but is highly uncertain [133, 134].

When changes in anthropogenic emissions of key precursors are considered, the impact on $\mathrm{OH} \cdot$ depends on the emission scenario. In three of the RCPs, the effects of declining anthropogenic $\mathrm{NO}_{x}$ and hydrocarbons tend to cancel each other, allowing the influence of climate change to dominate the $\mathrm{OH} \cdot$ trend. In RCP8.5, however, the large rise in anthropogenic methane swamps the climate effect and leads to strong decreases. For example, John et al. [116] determined that greater water vapor abundance by 2100 enhances global $\mathrm{OH} \cdot$ by $7-9 \%$ relative to the present day for RCP2.6 and RCP4.5, with little change in RCP6.0. In contrast, global $\mathrm{OH} \cdot$ declines by nearly $15 \%$ in the $\mathrm{CH}_{4}$-rich $\mathrm{RCP} 8.5$ scenario over the same time period. The multi-model study of Voulgarakis et al. [13], however, reveals large uncertainties in such projections, with intermodel differences as large as the differences between scenarios. While the three scenarios with the lowest target radiative forcing all project modest increases in $\mathrm{OH}$ by 2100 , the uncertainties swamp the median result [13]. RCP2.6, for example, yields a change in global $\mathrm{OH} \cdot$ of $+3.7 \pm 9.0 \%$ by 2100 relative to the present day. These intermodel differences are smaller in the RCP 8.5 scenario on account of the strong influence of the doubled methane burden, leading to a decrease in global $\mathrm{OH} \cdot$ of $-11.3 \pm 7.7 \%$ by 2100. The decrease in $\mathrm{OH} \cdot$ in RCP8.5 lengthens the methane lifetime, resulting in a positive feedback for this key greenhouse gas $[13,135]$.

Besides $\mathrm{OH}$, the other oxidants are also expected to respond to global change. Results from multi-model ensembles suggest that the tropospheric $\mathrm{O}_{3}$ burden may decrease by 5$16 \%$ by 2100 in RCP2.6, RCP4.5, and RCP6.0, as anthropogenic emissions of $\mathrm{NO}_{x}$ and hydrocarbons decline [33, 136]. In contrast, models predict that tropospheric $\mathrm{O}_{3}$ could increase by $15-20 \%$ in RCP 8.5 due to the doubling of methane [33, 136, 137]. Consideration of the effects of increasing stratospheric $\mathrm{O}_{3}$ also enhances tropospheric $\mathrm{O}_{3}$, mainly in the Northern Hemisphere [121]. Trends in $\mathrm{H}_{2} \mathrm{O}_{2}$ in the future atmosphere are expected to follow trends in $\mathrm{OH}$, though warmer temperatures could accelerate $\mathrm{H}_{2} \mathrm{O}_{2}$ production via $\mathrm{HO}_{2} \cdot+\mathrm{HO}_{2} \cdot \rightarrow \mathrm{H}_{2} \mathrm{O}_{2}$ [138]. $\mathrm{NO}_{3} \cdot$ concentrations will likely decline in the future atmosphere, following projections in anthropogenic $\mathrm{NO}_{x}$ emissions [139]. Taken together, these projections of the oxidative capacity of future atmosphere underscore the uncertainty not just in current scientific knowledge but also in the socioeconomic paths that societies will follow.

\section{Conclusions}

Although all of the observational constraints for past atmospheres are uncertain to varying degrees, they suggest a common theme that models underestimate the sensitivity of oxidant $\left(\mathrm{OH} \cdot \mathrm{O}_{3}\right)$ abundances to anthropogenic and climate impacts (Table 1). In general, models tend to underestimate changes implied by a variety of paleo-observational constraints on both short (past 200 years) and longer (past $\sim 100,000$ years) time scales. There is high confidence that anthropogenic activities have increased the abundance of tropospheric $\mathrm{O}_{3}$; however, models cannot reproduce the magnitude of the change implied by the observations over the past 100 years. While ice-core observations of $\mathrm{HCHO} / \mathrm{CH}_{4}$ imply a decrease in $\mathrm{OH} \cdot$ over the last 200 years, models cannot yet agree on either the sign or magnitude of the change in $\mathrm{OH} \cdot$. A recent global model [44] underestimates the decrease in the $\mathrm{O}_{3} /\left(\mathrm{HO}_{2} \cdot+\mathrm{RO}_{2} \cdot\right)$ ratio inferred by ice-core observations of $\Delta^{17} \mathrm{O}\left(\mathrm{NO}_{3}{ }^{-}\right)$in South America over the past 150 years [24]. Few observational constraints exist during large climate changes such as on the glacial-interglacial time scale. However, as with recent time scales, global models cannot agree on the sign or magnitude of the change in global mean $\mathrm{OH}$ from the LGM to the preindustrial. Although highly uncertain, paleo-observations $[45,79]$ suggest $50 \%$ higher global $\mathrm{OH}$ abundance in the LGM relative to the preindustrial, an enhancement larger than any reported by models. This result contrasts with future modeling studies that predict higher $\mathrm{OH} \cdot$ due to the effects of a warming climate alone (Wu et al. [8], and references therein).

Model sensitivity studies can point to the most important parameters that influence oxidant abundances on each time scale. Naik et al. [11] found that global $\mathrm{OH} \cdot$ abundance is most sensitive to the relative emissions of $\mathrm{NO}_{x}$ and $\mathrm{CH}_{4}$ over the 1980-2000 time frame. This result has important implications for future $\mathrm{OH}$, as estimates of $\mathrm{CH}_{4}$ emissions vary considerably between the different RCP scenarios. Murray et al. [30] found that three parameters can explain most of the modeled variability in global-mean $\mathrm{OH} \cdot$ over the glacial-interglacial time scale: (1) stratospheric $\mathrm{O}_{3}$ abundance via its influence on the photolysis frequency of tropospheric $\mathrm{O}_{3},(2)$ water vapor, and (3) lightning emission of $\mathrm{NO}_{x}$, largely consistent with conclusions of Holmes et al. [135] who examined future sensitivities. Achakulwisut et al. [44] demonstrated that the response of global-mean $\mathrm{OH} \cdot$ to climate change is particularly sensitive to uncertainties in isoprene oxidation chemistry. In light of these model studies, the large changes in oxidants in past atmospheres inferred from proxy data suggest that stratospheric $\mathrm{O}_{3}$, water vapor, and/or lightning $\mathrm{NO}_{x}$ emissions may be much more sensitive to climate change than is currently estimated.

Can we gain information from the paleo-records about climate-induced variability of the most influential forcings for the oxidation capacity of the atmosphere? Polar stratospheric $\mathrm{O}_{3}$ abundance will influence ice-core $\delta^{15} \mathrm{~N}\left(\mathrm{NO}_{3}{ }^{-}\right)$in regions of low snow accumulation rate such as the East Antarctic Plateau where variability in $\delta^{15} \mathrm{~N}\left(\mathrm{NO}_{3}{ }^{-}\right)$is governed by UV-photolytic loss $[93,94]$. Information on stratospheric $\mathrm{O}_{3}$ 
over polar regions can, in turn, inform our understanding of past variability in global stratospheric $\mathrm{O}_{3}$. Such a proxy could be easily calibrated by measuring $\left.\delta^{15} \mathrm{~N}_{\left(\mathrm{NO}_{3}\right.}{ }^{-}\right)$before and during the modern-day stratospheric $\mathrm{O}_{3}$ depletion. For lightning $\mathrm{NO}_{x}$, measurements of $\delta^{15} \mathrm{~N}\left(\mathrm{NO}_{3}{ }^{-}\right)$could again prove useful, but from regions of high snow accumulation rates such as Greenland and West Antarctica. In these regions, ice-core $\left.\delta^{15} \mathrm{~N} \mathrm{NO}_{3}{ }^{-}\right)$could track changes in the emission strength of lightning $\mathrm{NO}_{x}$, which is thought to have a relatively high $\delta^{15} \mathrm{~N}$ signature [140], compared to that of other natural $\mathrm{NO}_{x}$ sources such as soil microbes [141] and biomass burning [95]. However, care must be taken when interpreting such data sets since the signature of $\delta^{15} \mathrm{~N}$ from $\mathrm{NO}_{x}$ sources may be overwritten by subsequent atmospheric or post-depositional processing [95]. Variability in water vapor abundance is governed by sea-surface temperature, making knowledge of this parameter essential for evaluating past global-mean $\mathrm{OH} \cdot$ abundance. Finally, present-day field campaigns combined with modeling studies are required to advance our understanding of $\mathrm{HO}_{x}$ cycling during oxidation of isoprene, especially under low$\mathrm{NO}_{x}$ conditions.

Of all proxies for past oxidant abundances, $\Delta^{17} \mathrm{O}$ of nitrate and $\mathrm{CO}$ appear the most promising proxies over longer time scales due to their unique sensitivity to oxidant abundances combined with their high degree of preservation in polar ice. Only two records of ice-core $\Delta^{17} \mathrm{O}\left(\mathrm{NO}_{3}{ }^{-}\right)$have been published to date $[24,100]$, and these suggest significant anthropogenic influence on the $\mathrm{O}_{3} /\left(\mathrm{HO}_{2} \cdot+\mathrm{RO}_{2} \cdot\right)$ ratio in the mid- to high-latitudes [24]. Measurements of ice-core $\Delta^{17} \mathrm{O}\left(\mathrm{NO}_{3}{ }^{-}\right)$ on the glacial-interglacial time scale are in progress. $\Delta^{17} \mathrm{O}(\mathrm{CO})$ has not yet been measured in ice cores, but a modeling study suggests that $\Delta^{17} \mathrm{O}(\mathrm{CO})$ may indeed be a useful indicator of past $\mathrm{OH} \cdot$ abundance [115]. As all paleoclimate and paleo-chemistry proxies are inherently uncertain, information from multiple proxies will be required for robust constraints on past variability in the oxidizing capacity of the atmosphere. Such constraints can be used to inform potential future changes in the oxidizing capacity of the atmosphere and the implications for air pollution.

Acknowledgments B. Alexander acknowledges the support from NSF-AGS 1103163, NSF-PLR 1106317, NSF-PLR 1244817, and NSF-PLR 1446904. L. J. Mickley acknowledges the support from NSF-AGS 1102880.

Conflict of Interest Becky Alexander and Loretta J. Mickley declare that they have no conflict of interest.

\section{References}

1. Jaeglé L, Steinberger L, Martin RV, Chance K. Global partitioning of $\mathrm{NO}_{\mathrm{x}}$ sources using satellite observations: relative roles of fossil fuel combustion, biomass burning and soil emissions. Faraday Discuss. 2005;130:407-23.
2. Cooper OR, Parrish DD, Ziemke J, Balashov NV, Cupeiro M, Galbally IE, et al. Global distribution and trends of tropospheric ozone: an observation-based review. Elem: Sci Anthropocene. 2014;2(000029):1-28.

3. Parrish DD, Law KS, Staehelin J, Derwent R, Cooper OR, Tanimoto H, et al. Long-term changes in lower tropospheric baseline ozone concentrations at northern mid-latitudes. Atmos Chem Phys. 2012;12:11485-504.

4. Montzka SA, Krol M, Dlugokencky E, Hall B, Jockel P, Lelieveld J. Small interannual variability of global atmospheric hydroxyl. Science. 2011;331(6013):67-9.

5. Lelieveld J, Peters W, Dentener F, Krol M. Stability of tropospheric hydroxyl chemistry. J Geophys Res. 2002;107(D23):4715.

6. Fiore AM, LW Horowitz, EJ Dlugokencky, and JJ West. Impact of meteorology and emissions on methane trends, 1990-2004. Geophys Res Lett. 2006; 33(L12809). doi:10.1029/ 2006GL026199.

7. Brasseur GP, Schultz M, Granier C, Saunois M, Diehl T, Botzet $\mathrm{M}$, et al. Impact of climate change on the future chemical composition of the global troposphere. J Clim. 2006;19(16):3932-51.

8. Wu S, Mickley LJ, Kaplan JO, Jacob DJ. Impacts of changes in land use and land cover on atmospheric chemistry and air quality over the 21st century. Atmos Chem Phys. 2012;12(3):1597-609.

9. Unger N. Human land-use-driven reduction of forest volatiles cools global climate. Nat Clim Chang. 2014;4:907-10.

10. Rohrer F, Berresheim H. Strong correlation between levels of tropospheric hydroxyl radicals and solar ultraviolet radiation. Nature. 2006;442:184-7.

11. Naik V, Voulgarakis A, Fiore AM, Horowitz LW, Lamarque J-F, Lin M, et al. Preindustrial to present-day changes in tropospheric hydroxyl radical and methane lifetime from the Atmospheric Chemistry and Climate Model Intercomparison Project (ACCMIP). Atmos Chem Phys. 2013;13:5277-98.

12. van Vuuren DP, Edmonds JA, Kainuma M, Riahi K, Thomson AM, Hibbard KA, et al. The representative concentration pathways: An overview. Clim Chang. 2011;109(1-2):5-31.

13. Voulgarakis A, Naik V, Lamarque JF, Shindell DT, Young PJ, Prather MJ, et al. Analysis of present day and future $\mathrm{OH}$ and methane lifetime in the ACCMIP simulations. Atmos Chem Phys. 2013;13(5):2563-87.

14. Etheridge DM, Steele LP, Francey RJ, Langenfelds RL. Atmospheric methane between 1000 A.D. and present: evidence of anthropogenic emissions and climatic variability. J Geophys Res. 1998;103(D13):15979-93.

15. Barnola J-M, Anklin M, Porcheron J, Raynaud D, Schwander J, Stauffer B. CO2 evolution during the last millennium as recorded by Antarctic and Greenland ice. Tellus. 1995;47B:264-72.

16. Dlugokencky EJ, Steele LP, Lang PM, Masarie KA. Atmospheric methane at Mauna-Loa and Barrow observatories - presentation and analysis of in-situ measurements. J Geophys Res. 1995;100(D11):23103-13.

17. Spahni R, Chappellaz J, Stocker TF, Loulergue L, Hausammann G, Kawamura K, et al. Atmospheric methane and nitrous oxide of the late Pleistocene from Antarctic ice cores. Science. 2005;310(5752):1317-21.

18. Loulergue L, Schilt A, Spahni R, Masson-Delmotte V, Blunier T, Lemieux B, et al. Orbital and millennial-scale features of atmospheric $\mathrm{CH}_{4}$ over the past 800,000 years. Nature. 2008;453(7193): 383-6.

19. Monnin E, Indermuhle A, Dallenbach A, Fluckiger J, Stauffer B, Stocker TF, et al. Atmospheric $\mathrm{CO}_{2}$ concentrations over the last glacial termination. Science. 2001;291:112-44.

20. Geng L, J Cole-Dai, B Alexander, A Lanciki. Recent decreases in anthropogenic aerosol load in the Arctic as observed from a Central Greenland ice core. J Geophys Res. 2015. 
21. Mayewski PA, Lyons WB, Spencer MJ, Twickler MS, Buck CF, Whitlow S. An ice-core record of atmospheric response to anthropogenic sulphate and nitrate. Nature. 1990;346:554-6.

22. Smith SJ, van Aardenne J, Klimont Z, Andres RJ, Volke A, Arias SD. Anthropogenic sulfur dioxide emissions: 1850-2005. Atmos Chem Phys. 2011;11:1101-16.

23. Duan K, Thompson LG, Yao T, Davis ME, Mosley-Thompson E. A 1000 year history of atmospheric sulfate concentrations in southern Asia as recorded by a Himalayan ice core. Geophys Res Lett. 2007;34, L01810.

24. Sofen ED, Alexander B, Steig EJ, Thiemens MH, Kunasek SA, Amos HM, et al. WAIS Divide ice core suggests sustained changes in the atmospheric formation pathways of sulfate and nitrate since the 19th century in the extratropical Southern Hemisphere. Atmos Chem Phys. 2014;14:5749-69.

25. Marenco A, Gouget H, Nedelec P, Pages JP, Karcher F. Evidence of a long-term increase in tropospheric ozone from Pic du Midi data series: consequences: positive radiative forcing. J Geophys Res. 1994;99:16617-32.

26. Volz A, Kley D. Evaluation of the Montsouris series of ozone measurements made in the nineteenth century. Nature. 1988;332: 240-2.

27. Sandroni S, Anfossi D, Viarengo S. Surface ozone levels at the end of the nineteenth century in South America. J Geophys Res. 1992;97(D2):2535-9.

28. Pavelin EG, Johnson CE, Rughooputh S, Toumi R. Evaluation of pre-industrial surface ozone measurements made using the Schonbein method. Atmos Environ. 1999;33:919-29.

29. Sofen ED, Alexander B, Kunasek SA. The impact of anthropogenic emissions on atmospheric sulfate production pathways, oxidants, and ice core $\Delta^{17} \mathrm{O}\left(\mathrm{SO}_{4}{ }^{2-}\right)$. Atmos Chem Phys. 2011;11: 3565-78.

30. Murray LT, Mickley LJ, Kaplan JO, Sofen ED, Pfeiffer M, Alexander B. Factors controlling variability in the oxidative capacity of the troposphere since the Last Glacial Maximum. Atmos Chem Phys. 2014; 14:3589-622.

31. Shindell DT, Faluvegi G, Unger N, Aguilar E, Schmidt GA, Koch DM, et al. Simulations of preindustrial, present-day, and 2100 conditions in the NASA GISS composition and climate model G-PUCCINI. Atmos Chem Phys Discus. 2006;6:4795-878.

32. Parrella JP, Jacob DJ, Liang Q, Zhang Y, Mickley LJ, Miller B, et al. Tropospheric bromine chemistry: implications for present and pre-industrial ozone and mercury. Atmos Chem Phys. 2012;12: 6723-40.

33. Young PJ, Archibald AT, Bowman KW, Lamarque J-F, Naik V, Stevenson DS, et al. Preindustrial to end 21st century projections of tropospheric ozone from the Atmospheric Chemistry and Climate Model Intercomparison Project (ACCMIP). Atmos Chem Phys. 2013;13(4):2063-90.

34. Valdes PJ, Beerling DJ, Johnson CE. The ice age methane budget. Geophys Res Lett. 2005;32, L02704.

35. Kaplan JO, Folberth G, Hauglustaine DA. Role of methane and biogenic volatile organic compound sources in late glacial and Holocene fluctuations of atmospheric methane concentrations. Glob Biogeochem Cycles. 2006;20:GB2016. doi:10.1029/ 2005GB002590

36. Sigg A, Neftel A. Evidence for a $50 \%$ increase in $\mathrm{H}_{2} \mathrm{O}_{2}$ over the past 200 years from a Greenland ice core. Nature. 1991;351:5579.

37. Anklin M, Bales RC. Recent increase in $\mathrm{H}_{2} \mathrm{O}_{2}$ concentration at Summit. Greenland J Geophys Res. 1997;102:19099-104.

38. Fuhrer K, Neftel A, Anklin M, Maggi V. Continuous measurements of hydrogen peroxide, formaldehyde, calcium and ammonium concentrations along the new GRIP ice core from Summit, Central Greenland. Atmos Environ. 1993;27A(12):1873-80.
39. Lamarque JF, McConnell JR, Shindell DT, Orlando JJ, Tyndall GS. Understanding the drivers for the 20th century change of hydrogen peroxide in Antarctic ice-cores. Geophys Res Lett. 2011;38, L04810.

40. Gillett RW, Van Ommen TD, Jackson AV, Ayers GP. Formaldehyde and peroxide concentrations in Law Dome (Antarctica) firn and ice cores. J Glaciol. 2000;46(152):15-9.

41. Lamarque J-F, Hess P, Emmons L, Buja L, Washington W, Granier C. Tropospheric ozone evolution between 1890 and 1990. J Geophys Res. 2005;110, D08304.

42. Staffelbach T, Neftel A, Stauffer B, Jacob DJ. A record of the atmospheric methane sink from formaldehyde in ice cores. Nature. 1991;349:603-5.

43. Bock J, Martinerie P, Witrant E, Chappelaz J. Atmospheric impacts and ice core imprints of a methane pulse from clathrates. Earth Planet Sci Lett. 2012;349-350:98-108.

44. Achakulwisut P, LJ Mickley, LT Murray, APK Tai, JO Kaplan, and B Alexander. Uncertainties in isoprene photochemistry and emissions: implications for the oxidative capacity of past and present atmospheres and for trends in short-lived climate forcers. In Prep, 2015.

45. Alexander B, Savarino J, Barkov NI, Delmas RJ, Thiemens MH. Climate driven changes in the oxidation pathways of atmospheric sulfur. Geophys Res Lett. 2002;29(14):30-4.

46. Mickley LJ, Jacob DJ, Rind D. Uncertainty in preindustrial abundance of tropospheric ozone: implications for radiative forcing calculations. J Geophys Res. 2001;106(D4):3389-99.

47. Neftel A, Jacob P, Klockow D. Measurements of hydrogen peroxide in polar ice samples. Nature. 1984;311:43-5.

48. Jacobi H-W, Frey MM, Hutterli MA, Bales RC, Schrems O, Cullen NJ, et al. Measurements of hydrogen peroxide and formaldehyde exchange between the atmosphere and surface snow at Summit. Greenland Atmos Environ. 2002;36(15-16):2619-28.

49. Hutterli MA, McConnell JR, Stewart RW, Jacobi HW, Bales RC. Impact of temperature-driven cycling of hydrogen peroxide $(\mathrm{H} 2 \mathrm{O} 2)$ between air and snow on the planetary boundary layer. J Geophys Res. 2001;106(D14):15395-404.

50. Beine H, Anastasio C. The photolysis of flash-frozen dilute hydrogen peroxide solutions. J Geophys Res. 2011;116, D14302.

51. Chu L, Anastasio C. Formation of hydroxyl radical from the photolysis of frozen hydrogen peroxide. J Phys Chem A. 2005;109: 6264-71.

52. Hullar T, Patten K, Anastasio C. Formation of hydrogen peroxide from illuminated polar snows and frozen solutions of model compounds. Atmos Environ. 2012;55:127-34.

53. Hullar T, Anastasio C. Modeling the influence of photochemistry on hydrogen peroxide concentrations in an Arctic snowpack. Geophys Res Lett. 2013;40:2694-8.

54. Neftel A, Jacob P, Klockow D. Long-term record of $\mathrm{H}_{2} \mathrm{O}_{2}$ in polar ice cores. Tellus. 1986;38B:262-70.

55. Frey MM, Bales RC, McConnell JR. Climate sensitivity of the century-scale hydrogen peroxide $\left(\mathrm{H}_{2} \mathrm{O}_{2}\right)$ record preserved in 23 ice cores from West Antarctica. J Geophys Res. 2006;111, D21301.

56. Möller D. New directions: explanation for the recent dramatic increase of $\mathrm{H} 2 \mathrm{O} 2$ concentrations found in Greenland ice cores. Atmos Environ. 1999;33:2435-7.

57. Ciais P, Sabine C, Bala G, Bopp L, Brovkin V, Canadell J, et al. Carbon and other biogeochemical cycles. In: Stocker RF et al., editors. Climate Change 2013: The Physical Science Basis. Contribution of Working Group I to the Fifth Assessment Report of the Intergovernmental Panel on Climate Change. Cambridge: Cambridge University Press; 2013.

58. Khalil MAK, Shearer MJ, Rasmusssen R. In: Kahlil MAK, editor. Atmospheric methane: sources, sinks, and role in global change. Berlin: Springer; 1993. 
59. Gierczak T, Talukdar RK, Herndon SC, Vaghjiani GL, Ravishankara AR. Rate coefficients for the reactions of hydroxyl radicals with methane and deuterated methanes. J Phys Chem A. 1997;101:3125-34.

60. Saueressig G, Crowley JN, Bergamaschi P, Bruhl C, Brenninkmeijer CAM, Fischer H. Carbon 13 and D kinetic isotope effects in the reactions of $\mathrm{CH}_{4}$ with $\mathrm{O}\left({ }^{1} \mathrm{D}\right)$ and $\mathrm{OH}$ : new laboratory measurements and their implications for the isotopic composition of stratospheric methane. J Geophys Res. 2001;106(D19):23127-8.

61. Cantrell CA, Shetter RE, McDaniel AH, Calvert JG, Davidson JA, Lowe DC, et al. Carbon kinetic isotope effect in the oxidation of methane by the hydroxyl radical. J Geophys Res. 1990;95(D13): 22455-62.

62. Allan W, H Struthers, and DC Lowe. Methane carbon isotope effects caused by atomic chlorine in the marine boundary layer: global model results compared with Southern Hemisphere measurements. J Geophys Res. 2007; 112(D04306). doi:10.1029/ 2006JD007369.

63. Platt $\mathrm{U}$, Allan $\mathrm{W}$, Lowe $\mathrm{D}$. Hemispheric average $\mathrm{Cl}$ atom concentration from ${ }^{13} \mathrm{C} /{ }^{12} \mathrm{C}$ ratios in atmospheric methane. Atmos Chem Phys. 2004;4:2393-9.

64. Saueressig G, Bergamaschi P, Crowley JN, Fischer H. Carbon kinetic isotope effect in the reaction of $\mathrm{CH} 4$ with $\mathrm{Cl}$ atoms. Geophys Res Lett. 1995;22(10):1225-8.

65. Tyler SC, Ajie HO, Rice AL, Cicerone RJ, Tuazon EC. Experimentally determined kinetic isotope effects in the reaction of $\mathrm{CH}_{4}$ with $\mathrm{Cl}$ : implications for atmospheric $\mathrm{CH}_{4}$. Geophys Res Lett. 2000;27(12):1715-8.

66. Tyler SC, Crill PM, Brailsford GW. ${ }^{13} \mathrm{C} /{ }^{12} \mathrm{C}$ fractionation of methane during oxidation in a temperate forested site. Geochem Cosmochem Acta. 1994;58:1625-33.

67. Snover AK, Quay PD. Hydrogen and carbon kinetic isotope effects during soil uptake of atmospheric methane. Glob Biogeochem Cycles. 2000;14(1):25-39.

68. Chappellaz JA, Fung IY, Thompson AM. The atmospheric methane increase since the Last Glacial Maximum. (1). Source estimates. Tellus. 1993;45B(3):228-41.

69. Craig H, Chou CC, Welhan JA, Stevens CM, Engelkemeir AG. The isotopic composition of methane in polar ice cores. Science. 1988;242(4885):1535-9.

70. Ferretti DF, Miller JB, White JWC, Etheridge DM, Lassey KR, Lowe DC, et al. Unexpected changes to the global methane budget over the past 2000 years. Science. 2005;309(5741):1714-7.

71. Houweling S, GR van der Werf, KK Goldewijk, T Röckmann, and I Aben. Early anthropogenic $\mathrm{CH}_{4}$ emissions and the variation of $\mathrm{CH}_{4}$ and ${ }^{13} \mathrm{CH}_{4}$ over the last millennium. Global Biogeochem Cycles. 2008; 22(GB1002).

72. Melton JR, Schaefer H, Whiticar MJ. Enrichment of ${ }^{13} \mathrm{C}$ of atmospheric $\mathrm{CH} 4$ during the Younger Dryas termination. Clim Past. 2012;8:1177-97.

73. Mischler JA, TA Sowers, RB Alley, MO Battle, JR McConnell, L Mitchell, et al. Carbon and hydrogen isotopic composition of methane over the last 1000 years. Global Biogeochem Cycles. 2009; 23(GB4024).

74. Möller L, Sowers T, Bock M, Spahini R, Behrens M, Schmitt J, et al. Independent variations of $\mathrm{CH} 4$ emissions and isotopic composition over the past 160,000 years. Nat Geosci. 2013;6:885-90.

75. Sowers T, S Bernard, O Aballain, J Chappelaz, and J-M Barnola. Records of the $\mathrm{d}^{13} \mathrm{C}$ of atmospheric $\mathrm{CH}_{4}$ over the last 2 centuries as recorded in Antarctic snow and ice. Global Biogeochem Cycles. 2005; 19(GB2002).

76. Sowers T. Late quaternary atmospheric $\mathrm{CH} 4$ isotope record suggests marine clathrates are stable. Science. 2006;311:838-40.

77. Schaefer H, Whiticar MJ, Brook EJ, Petrenko VV, Ferretti DF, Severinghaus JP. Ice record of $\mathrm{d}^{13} \mathrm{C}$ for atmospheric $\mathrm{CH}_{4}$ across the Younger Dryas-Preboreal Transition. Science. 2006;313(5790):1109-12.

78. Sapart CJ, Monteil G, Prokopiou M, Van de Wal RSW, Kaplan JO, Sperlich P, et al. Natural and anthropogenic variations in methane sources during the past two millennia. Nature. 2012;490:85-8.

79. Fischer H, Behrens M, Bock M, Richter U, Schmitt J, Loulergue $\mathrm{L}$, et al. Changing boreal methane sources and constant biomass burning during the last termination. Nature. 2008;452(7189):8647.

80. Ghosh A, Patra PK, Ishijima K, Umezawa T, Ito A, Etheridge DM, et al. Variations in global methane sources and sinks during 1910 2010. Atmos Chem Phys. 2015;15:2595-612.

81. Rigby M, Manning AJ, Prinn RG. The value of high-frequency, high-precision methane isotopologue measurements for source and sink estimation. J Geophys Res. 2012;117, D12312.

82. Monteil G, Houweling S, Dlugokencky EJ, Maenhout G, Vaughn $\mathrm{BH}$, White JWC, et al. Interpreting methane variations in the past two decades using measurements of $\mathrm{CH} 4$ mixing ratio and isotopic composition. Atmos Chem Phys. 2011;11:9141-53.

83. Hutterli M, Rothlisberger R, Bales RC. Atmosphere-to-snow-tofirn transfer studies of $\mathrm{HCHO}$ at Summit. Greenland Geophys Res Lett. 1999;26:1691-4.

84. Neftel A, Bales RC, Jacob DJ. $\mathrm{H}_{2} \mathrm{O}_{2}$ and $\mathrm{HCHO}$ in polar snow and their relation to atmospheric chemistry. In: Delmas RJ, editor. Ice core studies of global biogochemical cycles. Berlin: SpringerVerlag; 1995. p. 249-64.

85. Levy H, Moxim WJ, Klonecki AA, Kasibhatla PS. Simulated tropospheric NOx: its evaluation, global distribution and individual source contributions. J Geophys Res. 1999;104(D21):26279306.

86. Lamarque J-F, Bond TC, Eyring V, Granier C, Heil A, Klimont Z, et al. Historical (1850-2000) gridded anthropogenic and biomass burning emissions of reactive gases and aerosols: methodology and application. Atmos Chem Phys. 2010;10:7017-39.

87. Röthlisberger R, Hutterli MA, Sommer S, Wolff EW, Mulvaney R. Factors controlling nitrate in ice cores: evidence from the Dome C deep ice core. J Geophys Res. 2000;105(D16):20565-72.

88. Wolff EW, Barbante C, Becagli S, Bigler M, Boutron CF, Castellano E, et al. Changes in environment over the last 800 , 000 years from chemical analysis of the EPICA Dome $\mathrm{C}$ ice core. Quat Sci Rev. 2010;29:285-95.

89. Mayewski PA, Meeker LD, Whitlow S, Twickler MS, Morrison $\mathrm{MC}$, Bloomfield $\mathrm{P}$, et al. Changes in atmospheric circulation and ocean ice cover over the North Atlantic during the last 41, 000 years. Science. 1994;263(5154):1747-51.

90. Yang QZ, Mayewski PA, Twickler MS, Whitlow S. Major features of glaciochemistry over the last 110,000 years in the Greenland Ice Sheet Project 2 ice core. J Geophys Res. 1997;102(D19):23289 99.

91. Röthlisberger R, Hutterli MA, Wolff EW, Mulvaney R, Fischer H, Bigler $\mathrm{M}$, et al. Nitrate in Greenland and Antarctic ice cores: a detailed description of post-depositional processes. Ann Glaciol. 2002;35:209.

92. Honrath RE, Peterson MC, Guo S, Dibb JE, Shepson PB, Campbell B. Evidence of $\mathrm{NO}_{\mathrm{x}}$ production within or upon ice particles in the Greenland snowpack. Geophys Res Lett. 1999;26(6):695-8.

93. Frey MM, Savarino J, Morin S, Erbland J, Martins JMF. Photolysis imprint in the nitrate stable isotope signal in snow and atmosphere of East Antarctica and implications for reactive nitrogen cycling. Atmos Chem Phys. 2009;9:8681-96.

94. Erbland J, Vicars WC, Savarino J, Morin S, Frey MM, Frosini D, et al. Air-snow transfer of nitrate on the East Antarctic PlateauPart 1: isotopic evidence for a photolytically driven dynamic equilibrium in summer. Atmos Chem Phys. 2013;13(13):6403-19. 
95. Geng L, B Alexander, J Cole-Dai, EJ Steig, J Savarino, ED Sofen, et al. Nitrogen isotopes in ice core nitrate linked to anthropogenic atmospheric acidity change. Proc Natl Acad Sci. 2014. early edition.

96. Berhanu TA, Meusinger C, Erbland J, Jost R, Bhattacharya SK, Johnson MS, et al. Laboratory study of nitrate photolysis in Antarctica snow. II. Isotopic effects and wavelength dependence. J Chem Phys. 2014;140:244306.

97. Blunier T, Floch GL, Jacobi HW, Quansah E. Isotopic view on nitrate loss in Antarctic surface snow. Geophys Res Lett. 2005;32(13), L13501.

98. Michalski GM, Scott Z, Kabiling M, Thiemens MH. First measurements and modeling of $\mathrm{D}^{17} \mathrm{O}$ in atmospheric nitrate. Geophys Res Lett. 2003;30(16):1870. doi:10.1029/2003GL017015.

99. Fibiger DL, Hastings MG, Dibb JE, Huey LG. The preservations of atmospheric nitrate in snow at Summit, Greenland. Geophys Res Lett. 2013;40(13):3484-9.

100. Alexander B, Savarino J, Kreutz KJ, Thiemens MH. Impact of preindustrial biomass-burning emissions on the oxidation pathways of tropospheric sulfur and nitrogen. J Geophys Res. 2004;109, D08303.

101. Legrand MR, Hammer CU, Angelis MD, Savarino J, Delmas R, Clausen HB, et al. Sulfur-containing species (methanesulfonate and SO4) over the last climatic cycle in the Greenland Ice Core Project (central Greenland) ice core. J Geophys Res. 1997;102: 26663-79.

102. Park RJ, Jacob DJ, Field BD, Yantosca RM, Chin M. Natural and transboundary pollution influences on sulfate-nitrate-ammonium aerosols in the United States: implications for policy. J Geophys Res. 2004;109, D15204.

103. Savarino J, Lee CCW, Thiemens MH. Laboratory oxygen isotopic study of sulfur (IV) oxidation: origin of the mass-independent isotopic anomaly in atmospheric sulfates and sulfate mineral deposits on Earth. J Geophys Res. 2000;105:29079.

104. Seiler W. The cycle of atmospheric CO. Tellus. 1974;26(1-2): 116-35.

105. Law KS, Pyle JA. Modeling trace gas budgets in the troposphere 2. $\mathrm{CH}_{4}$ and CO. J Geophys Res. 1993;98(D10):18401-12.

106. Karlsdottir S, Isaksen ISA. Changing methane lifetime: possible cause for reduced growth. Geophys Res Lett. 2000;27:93-6.

107. Faïn X, Chappellaz J, Rhodes RH, Stowasser C, Blunier T, McConnell JR, et al. High resolution measurements of carbon monoxide along a late Holocene Greenland ice core: evidence for in-situ production. Clim Past Discuss. 2013;9:2817-57.

108. Haan D, Zuo Y, Gros V, Brenninkmeijer CAM. Photochemical production of carbon monoxide in snow. J Atmos Chem. 2001;40:217-30.

109. Haan D, Raynaud D. Ice core record of CO variations during the last two millennia: atmospheric implications and chemical interactions within the Greenland ice. Tellus Ser B-Chem Phys Meteorol. 1998;50:253-62.

110. Colussi AJ, Hoffmann MR. In situ photolysis of deep ice core contaminants by Çerenkovradiation of cosmic origin. Geophys Res Lett. 2003;30(4):1195.

111. Assonov SS, Brenninkmeijer CAM, Jockel P, Mulvaney R, Bernard S, Chappellaz J. Evidence for a CO increase in the SH during the 20th century based on firn air samples from Berkner Island, Antarctica. Atmos Chem Phys. 2007;7:295-308.

112. Wang Z, Chappellaz J, Park K, Mak JE. Large variations in Southern Hemisphere biomass burning during the last 650 years. Science. 2010;330:1663-6.

113. Huff AK, Thiemens MH. O-17/O-16 and O-18/O-16 isotope measurements of atmospheric carbon monoxide and its sources. Geophys Res Lett. 1998;25(18):3509.

114. Rockmann T, Brenninkmeijer CAM, Saueressig G, Bergamaschi $\mathrm{P}$, Crowley JN, Fischer H, et al. Mass-independent oxygen isotope fractionation in atmospheric $\mathrm{CO}$ as a result of the reaction $\mathrm{CO}+$ OH. Science. 1998;281(5376):544-6.

115. Levine JG, Wolff EW, Jones AE, Hutterli MA, Wild O, Carver $\mathrm{GD}$, et al. In search of an ice core signal to differentiate between source-driven and sink-driven changes in atmospheric methane. $\mathrm{J}$ Geophys Res. 2011;116, D05305.

116. John JG, Fiore AM, Naik V, Horowitz LW, Dunne P. Climate versus emission drivers of methane lifetime against loss by tropospheric OH from 1860-2100. Atmos Chem Phys. 2012;12(24): 12021-36.

117. Archibald AT, Levine JG, Abraham NL, Cooke MC, Edwards PM, Heard DE, et al. Impacts of HOx regeneration and recycling in the oxidation of isoprene: consequences for the composition of past, present and future atmospheres. Geophys Res Lett. 2011;38, L05804.

118. Long MS, Keene WC, Easter RC, Sander R, Liu X, Kerkweg A, et al. Sensitivity of tropospheric chemical composition to halogenradical chemistry using a fully coupled size-resolved multiphase chemistry-global climate system: halogen distributions, aerosol composition, and sensitivity of climate-relevant gases. Atmos Chem Phys. 2014;14:3397-425.

119. Wu S, Mickley LJ, Jacob DJ, Rind D, Streets DG. Effects of 2000-2050 changes in climate and emissions on global tropospheric ozone and the policy-relevant background surface ozone in the United States. J Geophys Res. 2008;113, D18212.

120. Romps DM, Seeley JT, Vollaro D, Moliari J. Projected increase in lightning strikes in the United States due to global warming. Science. 2014;346(6211):851-4.

121. Morgenstern O, Zeng G, Luke Abraham N, Telford PJ, Braesicke P, Pyle JA, et al. Impacts of climate change, ozone recovery, and increasing methane on surface ozone and the tropospheric oxidizing capacity. J Geophys Res. 2013;118(2):1028-41.

122. Voulgarakis A, Shindell DT, Faluvegi G. Linkages between ozone-depleting substances, tropospheric oxidation and aerosols. Atmos Chem Phys. 2013;13:4907-16.

123. Dentener FJ, Crutzen PJ. Reaction of $\mathrm{N}_{2} \mathrm{O}_{5}$ on tropospheric aerosols: impact on the global distributions of $\mathrm{NO}_{\mathrm{x}}, \mathrm{O}_{3}$, and $\mathrm{OH} . \mathrm{J}$ Geophys Res. 1993;98(D4):7149-63.

124. Mao J, Fan S, Jacob DJ, Travis KR. Radical loss in the atmosphere from $\mathrm{Cu}-\mathrm{Fe}$ redox coupling in aerosols. Atmos Chem Phys. 2013;13(2):509-19.

125. Ganzeveld L, Lelieveld J. Impact of Amazonian deforestation on atmospheric chemistry. Geophys Res Lett. 2004;31(6), L06105.

126. Tai APK, Mickley LJ, Heald CL, Wu S. Effect of $\mathrm{CO}_{2}$ inhibition on biogenic isoprene emission: implications for air quality under 2000-to-2050 changes in climate, vegetation, and land use. Geophys Res Lett. 2013;40:3479-83.

127. Kirschke S, Bousquet P, Ciais P, Saunois M, Canadell JG, Dlugokencky EJ, et al. Three decades of global methane sources and sinks. Nat Geosci. 2013;6(10):813-23.

128. Yue X, Mickley LJ, Logan JA, Kaplan JO. Ensemble projections of wildfire activity and carbonaceous aerosol concentrations over the western United States in the mid-21st century. Atmos Environ. 2013;77(C):767-80.

129. Bousquet P, Hauglustaine DA, Peylin P, Carouge CC, Ciais P. Two decades of $\mathrm{OH}$ variability as inferred by an inversion of atmospheric transport and chemistry of methyl chloroform. Atmos Chem Phys. 2005;5(10):2635-56.

130. Prinn RG, Huang J, Weiss RF, Cunnold DM, Fraser PJ, Simmonds PG, et al. Evidence for variability of atmospheric hydroxyl radicals over the past quarter century. Geophys Res Lett. 2005;32, L07809.

131. Patra PK, Krol MC, Montzka SA, Arnold T, Atlas EL, Lintner BR, et al. Observational evidence for interhemispheric hydoxyl-radical parity. Nature. 2014;513(7517):219-23. 
132. Shindell D, Pechony O, Voulgarakis A, Faluvegi G, Nazarenko L, Larmarque J-F, et al. Interactive ozone and methane chemistry in GISS-E2 historical and future climate simulations. Atmos Chem Phys. 2013;13:2653-89.

133. Schaefer K, Lantuit H, Romanovsky VE, Schuur EAG, Witt R. The impact of the permafrost carbon feedback on global climate. Environ Res Lett. 2014;9:1-10.

134. Schuur EAG, Abbott BW, Bowden WB, Brovkin V, Camill P, Canadell J, et al. Expert assessment of vulnerability of permafrost carbon to climate change. Clim Chang. 2013;119(2):359-747.

135. Holmes CD, Prather MJ, Søvde OA, Myhre G. Future methane, hydroxyl, and their uncertainties: key climate and emission parameters for future predictions. Atmos Chem Phys. 2013;13:285-302.

136. Eyring V, Arblaster JM, Cionni I, Sedlacek J, Perliwitz J, Young PJ, et al. Long-term ozone changes and associated climate impacts in CMIP5 simulations. J Geophys Res. 2013;118(10):5029-60.
137. Cionni I, Eyring V, Lamarque JF, Randel WJ, Stevenson DS, Wu F, et al. Ozone database in support of CMIP5 simulations: results and corresponding radiative forcing. Atmos Chem Phys. 2011;11(21):11267-92.

138. Liao H, Chen W-T, Seinfeld JH. Role of climate change in global predictions of future tropospheric ozone and aerosols. J Geophys Res. 2006;111(D12), D12304.

139. Shindell DT, Lamarque JF, Schultz MG, Flanner MG, Jiao C, Chin $\mathrm{M}$, et al. Radiative forcing in the ACCMIP historical and future climate simulations. Atmos Chem Phys. 2013;13(6):2939-74.

140. Hoering T. The isotopic composition of the ammonia and the nitrate ion in rain. Geochem Cosmochem Acta. 1957;12:97-102.

141. Moore $\mathrm{H}$. The isotopic composition of ammonia, nitrogen dioxide, and nitrate in the atmosphere. Atmos Environ. 1977;42(19):1239 43. 